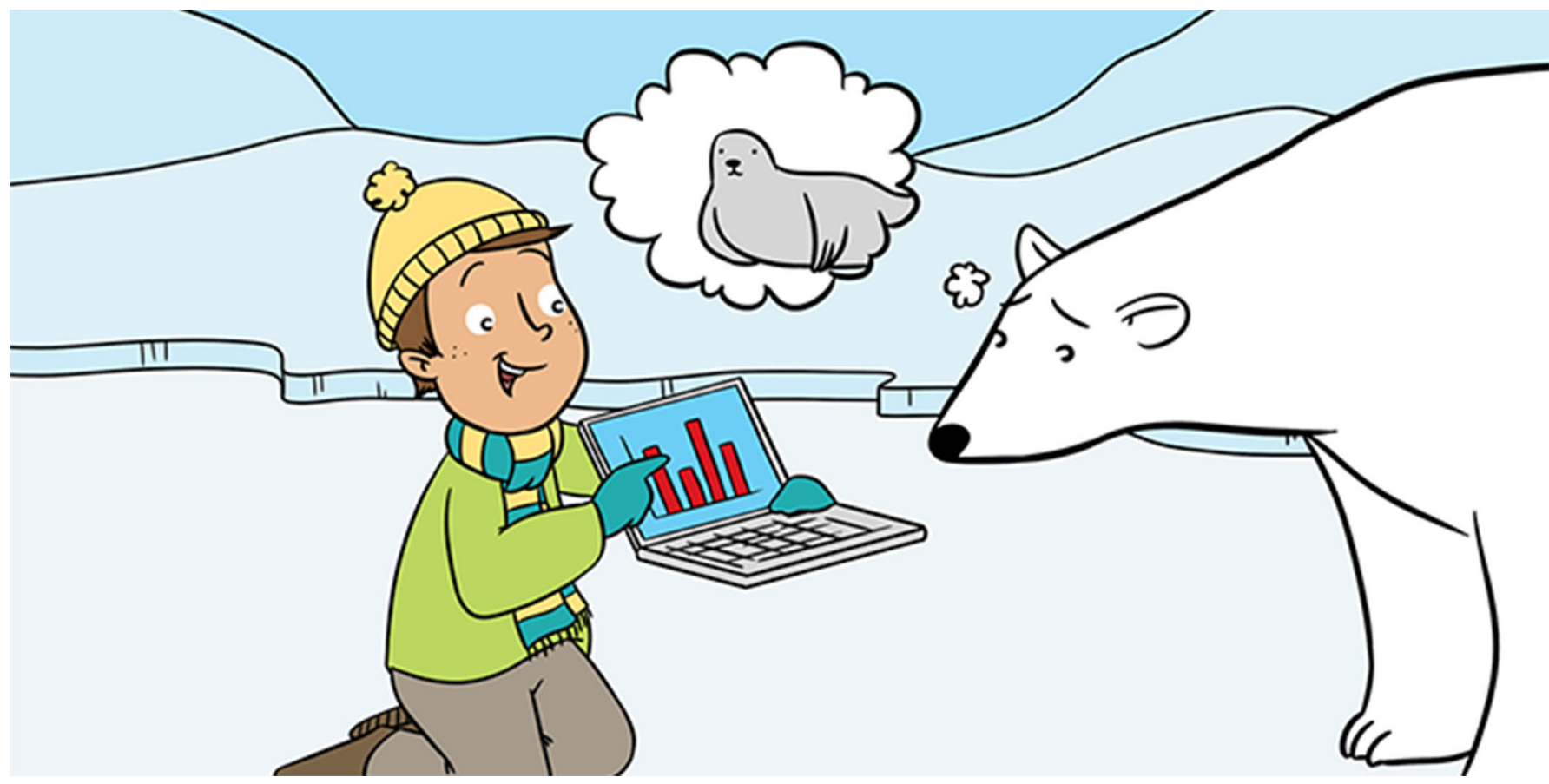

\title{
HOW IS CLIMATE CHANGE AFFECTING MARINE LIFE IN THE ARCTIC?
}

Michael R. Heath ${ }^{1 *}$, Deborah Benkort ${ }^{2}$, Andrew S. Brierley ${ }^{3}$, Ute Daewel ${ }^{2}$, Richard Hofmeister ${ }^{2}$, Jack H. Laverick ${ }^{1}$, Roland Proud ${ }^{3}$ and Douglas C. Speirs ${ }^{1}$

${ }^{1}$ Department of Mathematics and Statistics, University of Strathclyde, Glasgow, United Kingdom

${ }^{2}$ Helmholtz-Zentrum Geesthacht, Centre for Materials and Coastal Research, Geesthacht, Germany

${ }^{3}$ Scottish Oceans Institute, School of Biology, University of St. Andrews, St. Andrews, United Kingdom

YOUNG REVIEWER:

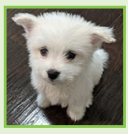

LILU

AGE: 11
Rising temperatures are melting the ice that covers the Arctic Ocean, allowing sunlight into waters that have been dark for thousands of years. Previously barren ice-covered regions are being transformed into productive seas. In this article, we explain how computer modeling can be used to predict how this transformation will affect the food web that connects plankton to fish and top predators, like whales and polar bears. Images of starving polar bears have become symbolic of the effects of the warming climate. Melting of the sea-ice is expected to reduce the bears' ability to hunt for seals. However, at the same time, the food web upon which bears depend is becoming more productive, so it is not completely clear what the eventual outcome will be. Computer models help us to understand these systems and help us make policy decisions about the management of newly available Arctic resources. 


\section{SEA-ICE}

Floating ice formed by freezing of the sea surface.

\section{Figure 1}

Changes in sea-ice extent (white areas) in the Arctic between 1979 and 2018. On the left, you can see the ice area in April when it is cold and the ice is at a maximum. On the right, you can see the ice area in September when it is warmer and the ice is at a minimum. Each map is centered on the North Pole; land is shown in black, with North America in the lower-left corner, Russia in the top-right, and Europe in the lower-right. The red circle shows the Barents Sea, which is the area that has seen the greatest change in ice cover (source: https://www.ncdc.noaa. gov/snow-and-ice/ extent/).

\section{INTRODUCTION}

The poles are among the harshest environments on our planet. In the winter, the sun never rises, air temperatures are extremely cold, and snow and ice accumulate. In summer, the sun never sets, it is warmer, and the ice melts back toward the poles. However, there is no doubt that the amount of ice is shrinking as our planet gets warmer. This is happening on the land and at sea. On the land, glaciers are melting and retreating in places like Antarctica, Greenland, and Alaska. At sea, the area of floating ice, which we call sea-ice, is becoming smaller each year [1] (Figure 1).

A National Geographic video of a starving polar bear with the caption "This is what climate change looks like" has become an internationally recognizable symbol of the effects of melting sea-ice on the Arctic ecosystem $[2,3]$. The story behind the video is that polar bears depend on being able to roam over the ice in search of seals to eat. Because the ice is shrinking they are struggling to find enough food. In this article, we explain why the story may be more complex than it first appears, and how computer models of ecosystems can be used to help us understand these complexities.

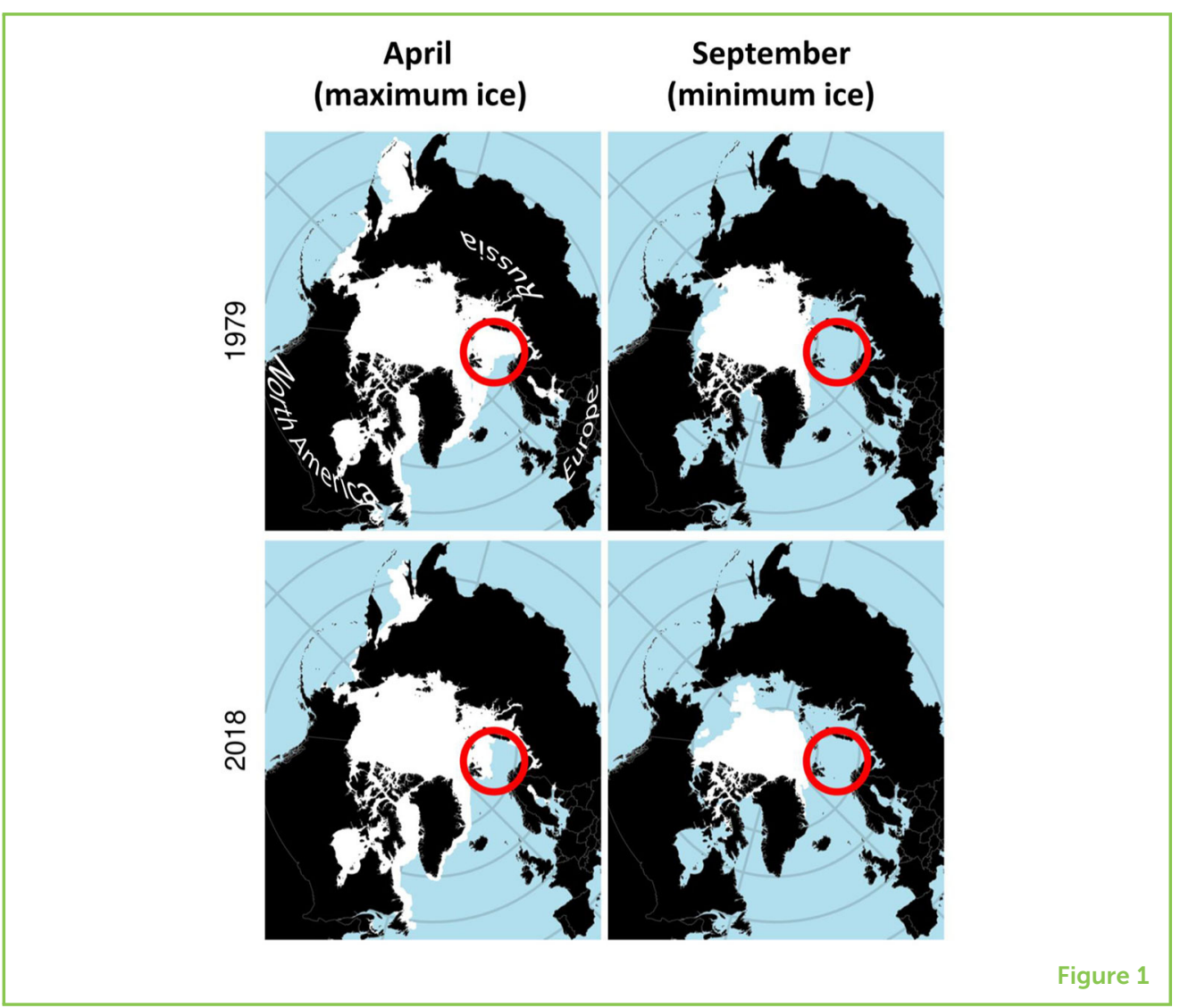


Figure 2

A who-eats-whom food web in the Arctic. The arrows connect each prey group to its predator group (Artwork: Douglas Speirs).

PHOTOSYNTHESIS

(FOH-TOH-SIN-

THI-SIS)

A chemical reaction in plants and some bacteria. It uses energy from light to convert carbon dioxide and water into organic compounds.

\section{PHYTOPLANKTON \\ (FIE-TOH- \\ PLANGKTUHN)}

Microscopic plants cells that drift in the water.

There are many species of phytoplankton.

\section{ZOOPLANKTON}

(ZOHUH-

PLANGKTUHN)

A general term for a huge variety of tiny animals that drift in the water.

\section{DETRITUS}

\section{(DI-TRIE-TUHS)}

Remains of dead organisms or waste produced by living organisms

\section{BENTHOS}

(BEN-THOS)

A general term for a huge range of animals that live in and on the seabed.

METABOLISM (MUHTAB-UH-LI-ZUHM)

The combination of chemical reactions required for life.

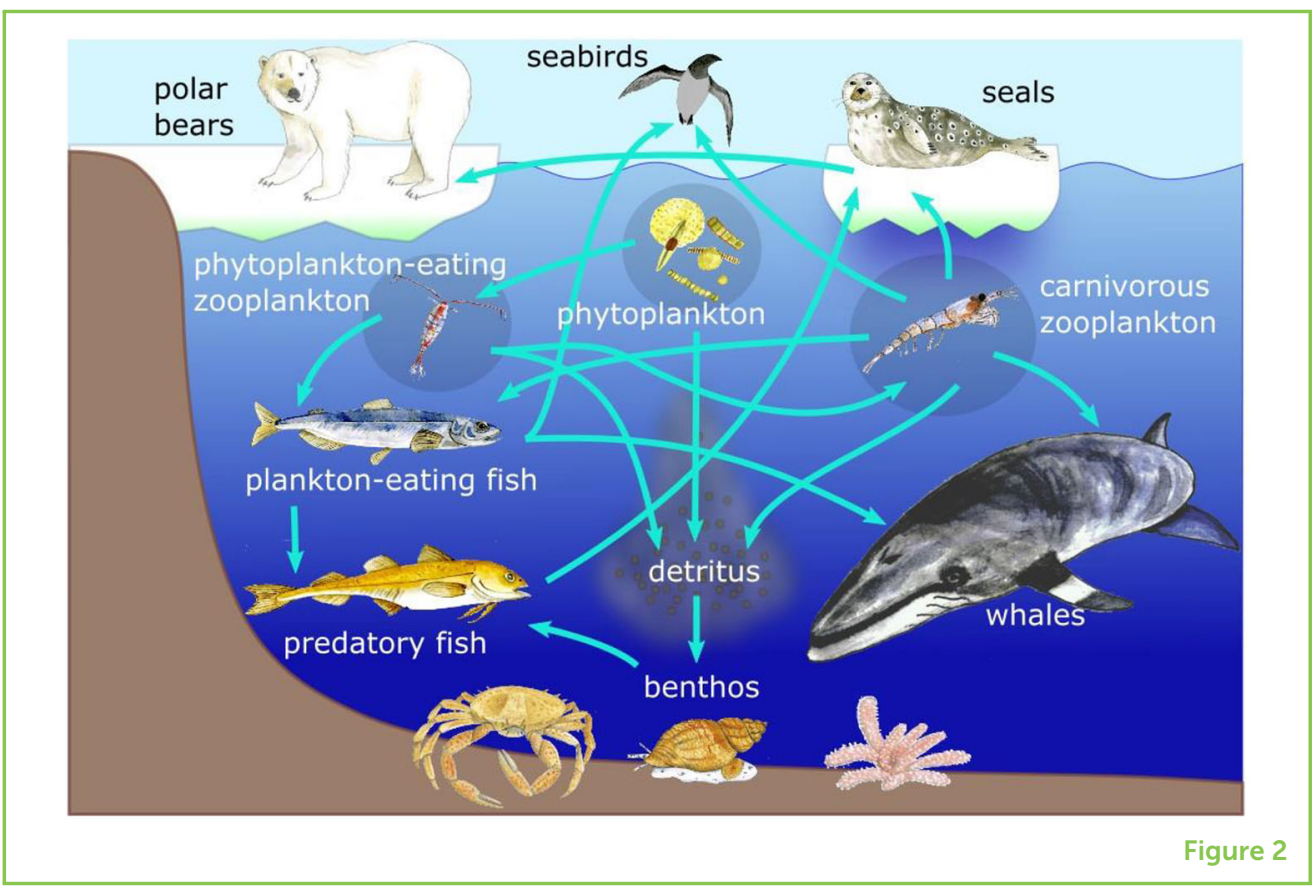

FOOD WEBS AND ECOSYSTEMS

An ecosystem is a community of bacteria, plants, and animals that occupy the same habitat. All the organisms in an ecosystem are interconnected by a network of who-eats-whom relationships. We call this a food web (Figure 2). Wherever there is sunlight and sufficient nutrients, plants manufacture the materials needed for life in a process called photosynthesis. Photosynthesis provides the energy to support all the animals in the rest of the food web.

In the sea, most of the plants are microscopic and we call them phytoplankton. Phytoplankton are eaten by a variety of tiny animals up to about the size of a grain of rice, called zooplankton. Zooplankton are then eaten by larger zooplankton, jellyfish, and plankton-eating fish, such as capelin. The waste they produce (called detritus) is broken down by bacteria as it falls to the seabed, where it provides food for bottom-living animals (called benthos). Plankton-eating fish and benthos are food for predatory fish, such as cod and hake, seabirds, and mammals, such as seals and whales. In the Arctic, all these animals are hunted by the top predators, such as polar bears. Humans are also top predators in the food web, because we catch fish and hunt for seals and whales.

\section{HOW IS WARMING OF THE PLANET AFFECTING ARCTIC FOOD WEBS?}

Warming has a direct effect on all living organisms. Metabolism depends on temperature [4]. Metabolism includes the processes that allow organisms to produce energy from the food that they eat. All 
organisms have a temperature range in which their metabolism can keep them living comfortably. Tropical species are less tolerant of cold conditions than polar species. This means that, as oceans warm, we expect species found in warm regions to expand their distributions, and we expect those species that prefer colder water to retreat toward the poles. Over the past 50 years, scientists have observed some zooplankton and fish species moving toward the poles, as the oceans become warmer [5].

The effects of warming on the sea-ice are also extremely important for the Arctic food webs. The presence of sea-ice strongly reduces the amount of sunlight that enters the ocean. The shrinking area of sea-ice (Figure 1) means that some parts of the ocean are being exposed to summer sunlight for the first time in many thousands of years. The light enables phytoplankton to grow and photosynthesize in areas that have previously been barren, increasing the productivity of the Arctic.

The increase in phytoplankton could be considered a positive change, leading to more life in the sea and more food for zooplankton, benthos, and eventually fish, birds, seals, whales, and polar bears [6]. However, some of the Arctic species have evolved to depend on the presence of ice. Sea-ice provides a means for seals and walruses to get out of the water. They need to do this to rest, breed, and evade other marine predators, such as killer whales. Other mammals, such as polar bears rely on the ability to travel across the frozen sea to hunt for seals. Melting ice makes travel more difficult because thin ice cannot support the bears' weight. On the other hand, ice is a barrier to whale species because they must be able to reach the air to breathe. Overall, it is not completely clear which of the predators in the food web will be benefited by melting sea-ice and which will be harmed by it.

\section{PREDICTING WHAT WILL HAPPEN IN THE ARCTIC}

We use computer models to make predictions about the effects that changes in sea ice will have on food webs. To make these models, we first write down the key processes and components of the food web as mathematical equations. These include feeding, metabolism, photosynthesis, and who-eats-whom. Then we convert the equations into computer code. This gives us a virtual world, in which we can carry out experiments on the model ecosystem. The experiments are designed to help us understand how the ecosystem could change in the future.

We built a simple model of the Barents Sea ecosystem in the Norwegian/Russian Arctic (Figure 1). This model contains data on ice and temperature conditions, and equations to represent some of what we know about the ecosystem's plants and animals. The main simplification is that some species are combined into groups that share similar characteristics, such as size, structure, or diet. For example, 
Figure 3

Results from a computer model comparing the mass of different components of the ecosystem (averaged over a year) in a possible future, warmer, ice-free Barents Sea, relative to the present day. Components in brackets are inorganic nutrients or dead material. Green bars to the right show that the quantity of a food web component is greater in the future model than in the present day. Conversely, red bars to the left indicate less mass of those components in the future model.

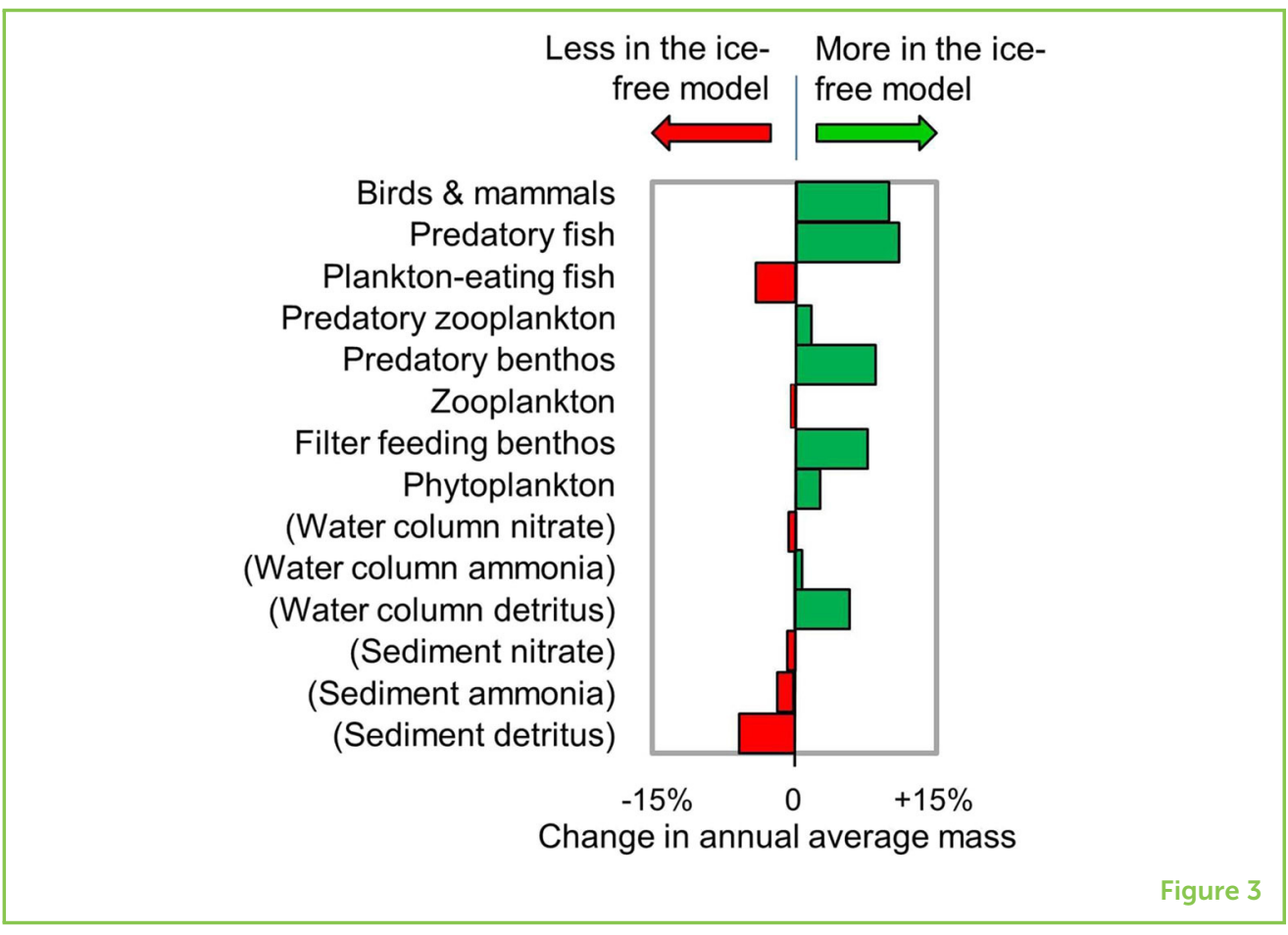

we combined all birds and mammals into a single group, because they are warm-blooded, which means that they can use energy from their food to maintain a warm body temperature independent of the environment, unlike plankton and most fish. This simplification means that, in our model, we cannot distinguish between polar bears and whales, for example. Although our simplified model is not perfect, it still reproduces the general responses of the natural Barents Sea ecosystem.

The equations in the model include parameters that determine the results. In our model, these include, for example, maximum feeding rates, or sinking rates of detritus. Selecting values for the parameters is an important step in building the model. We try to select values that allow the model to match as closely as possible to the real data from the ecosystem. This ensures that the model is as realistic as possible. Once the model is set up, we can change the ice and temperature conditions to what they might be in the future, and use the model to predict what may happen in real life. In Figure 3, we show an example of a comparison between the present day and future model results. The present-day model represents the Barents Sea as it is today. The future model is ice-free, with water temperatures $0.5^{\circ} \mathrm{C}$ warmer all year round. As expected, photosynthesis is higher in the future model. The animals that benefit are benthos, predatory fish, and the bird-and-mammal group. Zooplankton and plankton-eating fish are less abundant than they are today. This is because phytoplankton and detritus, upon which the benthos and zooplankton feed, settle to the seabed more quickly when there is no ice. Since we cannot distinguish between different bird and mammal predators in this 
model, we cannot use it to say exactly which species will be more abundant or less abundant in the future. However, the model predicts that the bird-and-mammal group as a whole will have a diet different from today's, with more feeding on predatory fish and less on planktivorous fish.

\section{WHY DOES ALL THIS MATTER?}

The Arctic is warming faster than the rest of the planet. Yearly averaged air temperatures in the Arctic have increased by around $2^{\circ} \mathrm{C}$ between 1970 and 2010 compared to $0.6^{\circ} \mathrm{C}$ for the planet as a whole [7]. Summer temperatures in the Canadian Arctic are now higher than at any time in the last 44,000 years [8]. Within the period of a human lifespan, the Arctic Ocean has partially emerged from beneath thousands of years of sea-ice cover.

There is a race between nations to claim the seabed and resources in the Arctic as it emerges from the ice. New routes will become possible for ships to travel between Europe, Asia, and North America. On 30 November 2017, the EU and nine major fishing nations agreed not to develop fisheries in the Arctic Ocean until at least 2033. This is supposed to allow time for scientists to develop the models needed for managing the fish stocks in a sustainable way [9]. There is much research to be completed before we have a full understanding of the effects of warming on the Arctic.

\section{REFERENCES}

1. Comiso, J. C. 2012. Large decadal decline of the arctic multiyear ice cover. J. Clim. 25:1176-93. doi: 10.1175/JCLI-D-11-00113.1

2. Gibbens, S. 2017. Heart-Wrenching Video Shows Starving Polar Bear on Iceless Land. Available online at: https://www.nationalgeographic.com/news/2017/12/ polar-bear-starving-arctic-sea-ice-melt-climate-change-spd/

3. Mittermeier, C. G. 2018. Starving-Polar-Bear Photographer Recalls What Went Wrong. Available online at: www.nationalgeographic.com/magazine/2018/08/ explore-through-the-lens-starving-polar-bear-photo/

4. Gillooly, J. F., Brown, J. H., West, G. B., Savage, V. M., and Charnov, E. L. 2001. Effects of size and temperature on metabolic rate. Science 293:2248-51. doi: 10.1126/science.1061967

5. Kortsch, S., Primicerio, R., Fossheim, M., Dolgov, A. V., and Aschan, M. 2015. Climate change alters the structure of arctic marine food webs due to poleward shifts of boreal generalists. Proc. R. Soc. B Biol. Sci. 282:20151546. doi: 10.1098/rspb.2015.1546

6. Darnis, G., Robert, D., Pomerleau, C., Link, H., Archambault, P., Nelson, R. J., et al. 2012. Current state and trends in Canadian Arctic marine ecosystems: II. Heterotrophic food web, pelagic-benthic coupling, and biodiversity. Clim. Change 115:179-205. doi: 10.1007/s10584-012-0483-8 
7. IPCC. 2013. Climate Change 2013: The Physical Science Basis. Contribution of Working Group I to the Fifth Assessment Report of the Intergovernmental Panel on Climate Change. Cambridge; New York, NY: Cambridge University Press.

8. Miller, G. H., Lehman, J. J., Refsnider, K. A., Southon, J. R., and Zhong, Y. 2013. Unprecedented recent summer warmth in Arctic Canada. Geophys. Res. Lett. 40:5745-51. doi: 10.1002/2013GL057188

9. Hoag, H. 2017. Nations agree to ban fishing in Arctic Ocean for at least 16 years. Science. doi: 10.1126/science.aar6437

SUBMITTED: 29 October 2019; ACCEPTED: 07 July 2020; PUBLISHED ONLINE: 14 August 2020.

EDITED BY: Roxana Suehring, Stockholm University, Sweden

CITATION: Heath MR, Benkort D, Brierley AS, Daewel U, Hofmeister R, Laverick JH, Proud R and Speirs DC (2020) How Is Climate Change Affecting Marine Life in the Arctic? Front. Young Minds 8:103. doi: 10.3389/frym.2020.00103

CONFLICT OF INTEREST: The authors declare that the research was conducted in the absence of any commercial or financial relationships that could be construed as a potential conflict of interest.

COPYRIGHT @ 2020 Heath, Benkort, Brierley, Daewel, Hofmeister, Laverick, Proud and Speirs. This is an open-access article distributed under the terms of the Creative Commons Attribution License (CC BY). The use, distribution or reproduction in other forums is permitted, provided the original author(s) and the copyright owner(s) are credited and that the original publication in this journal is cited, in accordance with accepted academic practice. No use, distribution or reproduction is permitted which does not comply with these terms.

\section{YOUNG REVIEWER}

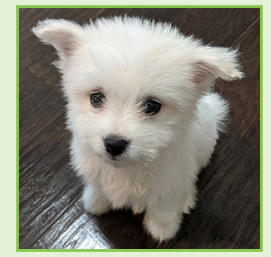

\section{LILU, AGE: 11}

I love polar bears and I am fighting against Climate Change to save them! I love my puppy and guinea pigs too.

\section{AUTHORS}
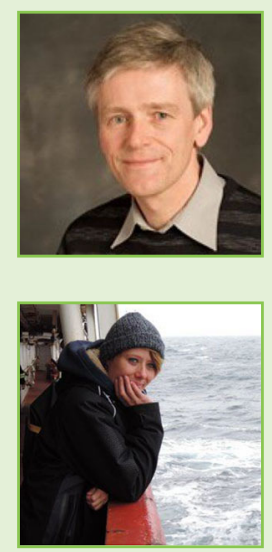

\section{MICHAEL R. HEATH}

I am a Professor in the Department of Mathematics and Statistics at the University of Strathclyde, Scotland, and I have been studying marine ecology for about 40 years. My current research interests are the mathematical and statistical modeling of fish populations and fisheries, and the dynamics of ecosystems. ${ }^{*}$ m. heath@strath.ac.uk

\section{DEBORAH BENKORT}

I am a scientist at the Helmholtz Zentrum Geesthacht, Germany, working on modeling the chemistry and plankton of the Arctic. During my Ph.D., my research focused on the zooplankton dynamic in the Gulf of St. Lawrence on the Canadian east coast. I developed models to study their growth and reproduction. 

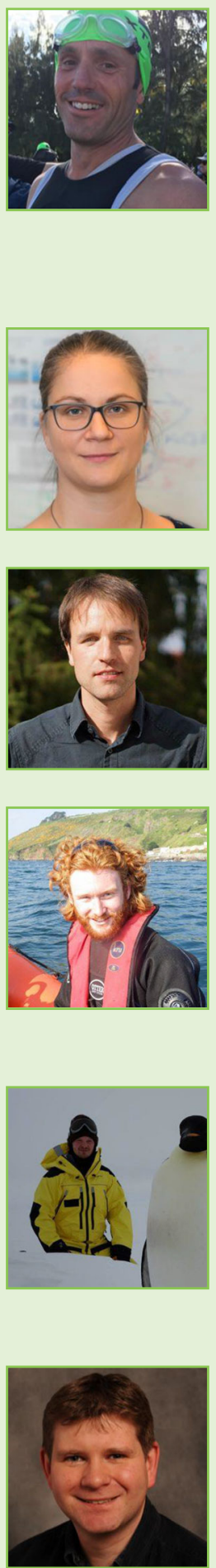

\section{ANDREW S. BRIERLEY}

I am an ecologist at the Scottish Oceans Institute, University of St. Andrews, Scotland. I have been studying polar seas since the 1990s. I specialize in using echo-sounders to study zooplankton and fish. However, I am presently working in Lake Victoria, East Africa. This is a long way from the Arctic, but lake ecosystems are governed by the same sorts of food-webs that we find in the sea so there is a common thread to my research.

\section{UTE DAEWEL}

I am a scientist at the Helmholtz-Zentrum Geesthacht, Germany. I am focused on investigating how physics affects the biology of different types of organisms in the sea. I am doing this by developing mathematical models. One major purpose of my recent research is to understand changes in the marine food web.

\section{RICHARD HOFMEISTER}

I received my Ph.D. in physical oceanography at the University of Rostock in Germany. My research at the Helmholtz-Zentrum Geesthacht and the University of Hamburg focuses on modeling of ocean currents to determine how plankton are transported in the seas.

\section{JACK H. LAVERICK}

I have a Ph.D. in environmental research from the University of Oxford, where I studied coral ecosystems in Honduras. I used a mixture of machine learning and modeling to investigate changing community structure across depth gradients. Currently, I am a post-doctoral researcher at the University of Stathclyde, Scotland.

\section{ROLAND PROUD}

I am a post-doctoral research fellow at the Scottish Oceans Institute, University of St. Andrews, Scotland. I have a Ph.D. in Marine Ecology, M.Phys. in Physics and Astrophysics and an M.Res. in ecosystem-based management of marine systems. I am carrying out research on the ecology and biology of zooplankton and micronekton that live in the open ocean.

\section{DOUGLAS C. SPEIRS}

I am a Senior Lecturer in the Department of Mathematics and Statistics at the University of Strathclyde, Scotland. My research involves developing computationally efficient population models of zooplankton and fish stocks. These models have detailed representations of biology, including the growth of individuals as they age, and the way their populations move across the ocean. 